\title{
WELFARE ASSESSMENT OF COMMERCIAL LAYERS IN SLOVENIA
}

\author{
Olga Zorman Rojs ${ }^{1 *}$, Alenka Dovč ${ }^{1}$, Hristo Hristov², Matjaž Červek ${ }^{3}$, Brigita Slavec ${ }^{1}$, Uroš Krapež ${ }^{1}$, Zoran Žlabravec ${ }^{1}$, Jožko \\ Račnik ${ }^{1}$, Manja Zupan ${ }^{4}$ \\ ${ }^{1}$ Institute for Poultry, Birds, Small Mammals, and Reptiles, Veterinary Faculty, University of Ljubljana, Gerbičeva $60,{ }^{2}$ Nutrition Institute, Tržaška

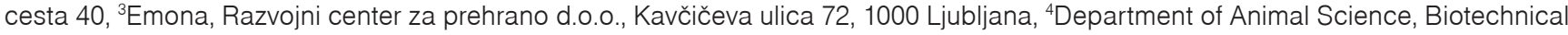 \\ Faculty, University of Ljubljana, Groblje 3, 1230 Domžale, Slovenia
}

${ }^{*}$ Corresponding author, E-mail: olga.zorman-rojs@vf.uni-lj.si

\begin{abstract}
Herewe present the first welfare assessment of commercial layers conducted in Slovenia. Hens were assessed in four systems at the beginning of the laying period at 22 to 24 weeks and at 50 to 55 weeks of age. These systems were an enriched battery cage system, an aviary, and a litter system with or without outdoor access. Clinical inspections of flocks were performed, and animal-based welfare indicators were scored (e.g., keel bone damage, feather condition, foot pad lesions, beak deformities, and comb and skin wounds). Hens' fear level was scored using the novel object test and avoidance distance test. Among resource-based measures, selected micro-climate parameters were measured.

The results showed no obvious clinical signs related to infectious diseases and suggest that the selected climate conditions were satisfying in all systems. Among animal-based welfare indicators, keel bone damage was shown to be the most serious problem connected with hens' age and housing systems $(p<0.05)$. Enriched cages and aviary system were associated with significantly more keel deformities compared to the litter systems $(p<0.05)$. In addition, the least prevalence of foot pad dermatitis together with better feather condition was observed in the litter systems. In the family-owned aviary facility, hens were found to be the most motivated to approach a novel object or a human, and as such were recognized as the least fearful birds, with better human-animal interaction compared to other intensive housing systems.
\end{abstract}

Key words: laying hens; welfare; health; housing system

\section{Introduction}

The welfare of laying hens in modern intensive production units has been recognized as an important aspect of poultry management. Several factors can influence the welfare of laying hens, such as diseases, skeletal health, behavior, stress, nutrition, genetics, and management. Housing systems may play a critical role in the welfare of laying hens, and various systems have been implemented throughout the world. In the European Union, conventional battery cages were the dominant housing system for laying hens until

Received: 4 October 2019

Accepted for publication:20 April 2020 their official ban on January 1st, 2012 (1). The ban on traditional cages was mainly adopted because of welfare concerns due to a lack of adequate space for performance of natural behaviors and an increased risk of bone deformities. According to an official report by the European Commission (2), enriched cages, aviaries, and floor housing are the most common housing systems used for commercial laying hens in the EU. In Slovenia, approximately 1.9 million hens are kept for egg production per year (3). Most hens (more than $40 \%$ ) are kept in enriched cages, around 39\% are kept in litter systems, including aviaries, and a smaller proportion of hens $(16.3 \%)$ are in facilities under free-range conditions $(2,4)$. 
Enriched cages were introduced to allow birds more movement; they have extra facilities such as a nest box and at least $15 \mathrm{~cm}$ of perch per hen. Floor housing and aviaries are non-cage systems. These systems have the same facilities as enrichment cages (i.e., perches and nest boxes), but the group size and litter area are considerably larger. In a floor system, all hens are in a facility on one level, whereas in aviaries they have access to at least two levels and as such aviary systems allow higher stocking densities. The systems encourage birds to carry out natural behaviors such as nesting and perching, and they provide access to floor litter. The aviary and floor housing systems have the distinct disadvantage that the birds are exposed to litter and excreta, creating potential health and food safety concerns.

Finding a reliable method to assess bird welfare has been slow, and it was only in 2009 that the first protocol was published, presenting a gold standard. The Welfare Quality ${ }^{\circledR}$ assessment protocol for poultry (5) is based on the concept that welfare is multidimensional, addressing both physical and mental health (6). It focuses on animal-based measures (e.g., injuries and behavior) as well as on resource-based measures (i.e., design or management criteria), making possible welfare comparisons across farms and housing systems.

Until now no assessment of commercial layers has been conducted focusing on welfare indicators in Slovenia. This study included hens from four systems: an enriched battery cage system, an aviary, and a litter system with or without outdoor access. The selected animal-based welfare indicators were keel bone damage, feather condition, foot pad lesions, beak deformities, and comb and skin wounds. Hens' behavior was scored using the novel object and avoidance distance test. To investigate the possible development of selected welfare indicators connected with age, assessments were performed at two time points: at the beginning of the laying period at 22 to 24 weeks, and at 50 to 55 weeks of age. In addition, selected climate parameters were measured at each assessment.

\section{Materials and methods}

\section{Animals and housing}

Four commercial flocks of Lohmann Brown hens were assessed in the study. The birds were beak trimmed in the hatchery and reared in a floor system or in an aviary system. At approximately 16 weeks of age the pullets were moved to commercial egg facilities. Pullets reared in a floor housing system were housed in either the enriched cage system (ECS) or the litter system with (LOS) or without (LS) outdoor access, whereas pullets reared in the aviary system were moved to the facility with the aviary system (AS). The flocks had a similar vaccination program; they were vaccinated against Marek disease, infectious bronchitis virus, infectious bursal disease virus, Newcastle disease virus, and Salmonella Enteritidis. The vaccinations were performed before transfer to commercial egg facilities. The flocks had the same feed supplier during the rearing and the laying period and were managed according to the same standard practices, but the owners of the facilities and the birds' keepers were different. The ECS was populated by 37,860 hens. The facility had four double-sided rows with three tiers, and each cage housed 20 hens. The cages were furnished with perches, nest boxes, a scratching pad, and a water line (Big Dutchman). The AS (Big Dutchman) was populated with 13,800 laying hens. The hens had perches, a forage area, nest space, and a litter area accessible to the hens to perform foraging and dust-bathing behaviors. The LS was populated by 3,820 hens. The facility was equipped with a nipple water system, a feeder line, an automatic nest system, and wood shavings (Roxell). The LOS was populated by 4,420 hens. The hens had the opportunity to go outside for 4 to 6 hours a day. The equipment of the facility was the same in both litter systems.

\section{Observations}

Each flock was visited two separate times during the laying period, at 22 to 24 weeks and 50 to 55 weeks of age. The visits took place between November 2016 and October 2017 and were carried out by the same observers. Information on farm and flock management (e.g., hybrid, flock size, and age when birds were introduced to the farm) as well as cumulative flock mortality (e.g., percentage of dead or culled hens) was collected from the farm records. At each visit, the following climate parameters were checked: temperature, ammonia $\left(\mathrm{NH}_{3}\right)$, relative humidity, and air velocity. Each parameter was measured at three locations within the facility. Temperature, relative humidity, and airflow were measured with a Testo 543 
instrument (Testo SE \& Co. KGaA, Germany), and the level of ammonia was measured using Dräger Multiwarn II (Dräger, UK). All measurements were performed at animal level, and the average values of three measurements of each parameter were calculated. General clinical flock observation was performed by walking throughout the facility, and each flock was checked for the presence of clinical signs of respiratory disorders, diarrhea, enlarged crops, and leg problems. Clinical indicators of health problems were scored on a three-point scale $(0=$ none, $1=$ fewer than three birds, $2=$ three or more birds). Infestation with Dermanyssus gallinae was checked by looking for the presence of the parasite on hens and on the surface of equipment and eggs.

The following parameters were additionally scored for presence and severity on an individual hen: foot abnormalities, feather condition, comb wound, skin lesions, beak abnormalities, and keel bone damage. A description of the physical condition measurements and severity scoring system is presented in Table 1 . Foot abnormalities were evaluated by examining both legs. Overall feather condition was evaluated by examination of the head, neck, back, and belly. For the assessment of skin lesions, the entire body of each hen was checked, including the region around the vent. Keel damage was determined by palpation to detect abnormal curvatures of the keel or bony callouses indicative of healed fractures. At each visit, 100 hens were examined in the AS and ECS, and 50 hens in the LOS and LS. Birds were caught individually from different locations in the facility and released after scoring.

Hens' behavior was scored using the novel object test (NOT) and the avoidance distance test (ADT) following the procedure described in the Welfare Quality ${ }^{\circledR}$ protocol. Both tests were performed after the clinical assessment of the flock to accustom the birds to human presence. The novel object (NO) used was a 45-cm stick with multicolored bands. In both litter facility systems and in the AS, the NO was placed in the litter area, and in the ECS the NO was placed in the feeder. At each visit, four locations in the facility were scored. The observer started to record the number of hens within one hen's distance of the NO (about $35 \mathrm{~cm}$ ) every $10 \mathrm{~s}$ for a total period of $2 \mathrm{~min}$. The average outcome of all four NOTs was calculated for each flock. The ADT was performed in 21 birds from different locations within each facility. In the AS, LS, and LOS the observer slowly approached the bird sitting on the edge of the slatted area.

Table 1: Description of physical condition measurements and severity scoring system

\begin{tabular}{ll}
\hline Condition & Score description \\
\hline Foot pad lesions & $=$ no lesion present \\
1 & $=$ proliferation of epithelium \\
2 & $=$ foot swelling dorsally visible \\
0 & $=$ completely or almost completely feathered, only single feathers damaged \\
1 & $=$ damaged feathers (worn, deformed) or one or more featherless areas $<5 \mathrm{~cm}$ \\
in diameter at largest extent & $2=$ at least one featherless area $\geq 5 \mathrm{~cm}$ in diameter at largest extent \\
\hline Feather condition & $=$ no wounds present \\
1 & $=<3$ fresh wounds present \\
2 & $=>3$ fresh wounds present \\
\hline Comb wound & $=$ no lesions present \\
1 & $=<3$ lesions present \\
2 & $=>3$ fresh wounds present \\
\hline Skin lesions & $=$ no trimming, no abnormalities \\
1 & $=$ moderate to light trimming with moderate to no abnormalities \\
2 & $=$ severe trimming with clear abnormalities \\
\hline Beak abnormalities & $=$ no deformation \\
1 & $=$ minor S-shape deviation \\
2 & $=$ severe keel deformities
\end{tabular}


When the hen turned away, the distance from the hand of the assessor to the bird was measured. In the cage house the observer walked down the corridor and approached a hen with her head out of the cage. As soon as the hen pulled her head into the cage, the distance between the observer and the front of the cage was estimated. The mean avoiding distance was calculated for each flock.

\section{Statistical analysis}

The Statistical Package for the Social Sciences was used for the statistical analyses. Variables of individual welfare measurements (beak and foot abnormalities, comb wounds and skin lesions, feather condition, and keel deformities) were analyzed using the non-parametric KruskalWallis test for comparison at each visit, followed by pair comparisons with the Wilcox Signed Rank test when significant $(p<0.05)$. The relationship between age and animal-based welfare indicators, and the association between housing system and animal-based welfare indicators were tested with Fisher's exact test $(p<0.05)$.

\section{Results}

\section{General observation of health and welfare}

The flocks examined were healthy at both visits. Signs of enteritis, eye abnormalities, respiratory disorders, leg problems, or pendulous crop were observed in fewer than three birds per flock at each visit. At the first visit no external parasites were detected, and good feather condition was noted in all the systems. At the second visit the AS hens showed greater feather loss compared to the other hens, but no signs of vent pecking were observed in any of the flocks. In the ECS birds, infestation with Dermanyssus gallinae was confirmed.

Cumulative flock mortality (percentage of dead or culled hens) is presented in Figure 1. At the first visit the lowest mortality was recorded in the ECS $(0.21 \%)$, followed by the AS $(0.56 \%)$ and both litter systems (0.9\%). At the second visit the mortality ranged from $2.1 \%$ in the AS to $4.79 \%$ in the LS (Figure 1).

The selected climate conditions recorded at each visit are presented in Table 2. The average $\mathrm{RH}$ values within facilities ranged from 55.3 to $74.2 \%$. The level of $\mathrm{NH}_{3}$ exceeded the anticipated level of 20 ppm only at the first visit in the LOS and LS.

\section{Specific observations}

\section{Beak abnormalities}

Although the birds were beak trimmed at the hatchery, at the first visit four hens from the ECS had intact beaks. Significantly more abnormalities were observed in the LOS hens ( $p$ $<0.05)$ compared to the hens from other systems. At the second visit, $12 \%$ of the birds examined from the AS and ECS were scored 2, whereas all hens from the LOS and LS were scored $1(p<0.05)$ (Figure 2).

\section{Comb wounds}

Comb wounds were rare. At the first observation no comb wounds were observed in the ECS, $\mathrm{AV}$, and LS, whereas in the LOS $18 \%$ of hens were scored 1. Significantly more wounds were confirmed in the LOS and ECS compared to the AS and LOS $(p<0.05)$. At an older age, no comb abnormalities were observed in the LOS, but they were noticed in individual birds from the other three systems. The highest score was obtained in the AS, but it did not significantly differ from the ECS and LS (Figure 3).

\section{Skin lesions}

At both visits, skin lesions were rarely detected, and no hen was scored 2. At the first visit, 1 to $4 \%$ of hens with a score of 1 were recorded in the ECS, LOS, and AS. Even better results were obtained at the second visit; mild skin lesions were detected in $2 \%$ of the AV and EC hens, but not in litter systems (data not shown). No significant differences were found between housing systems at any observation $(p>0.05)$.

\section{Foot abnormalities}

At the beginning of the laying period, no foot pad lesions were seen in the LOS and LS, whereas significantly more foot abnormalities $(p<0.05)$ were recorded in the ECS and AS; $6 \%$ of the ECS hens and $10 \%$ of the AS hens were scored 1 , and one hen $(2 \%)$ from the AS had severe inflammation (score 2). At the second visit, no score of 2 was recorded, although $16 \%$ of the ECS hens and $12 \%$ of the LOS hens had hyperkeratosis on one or both feet. In the AS or LS, only a few abnormalities were detected (Figure 4). 


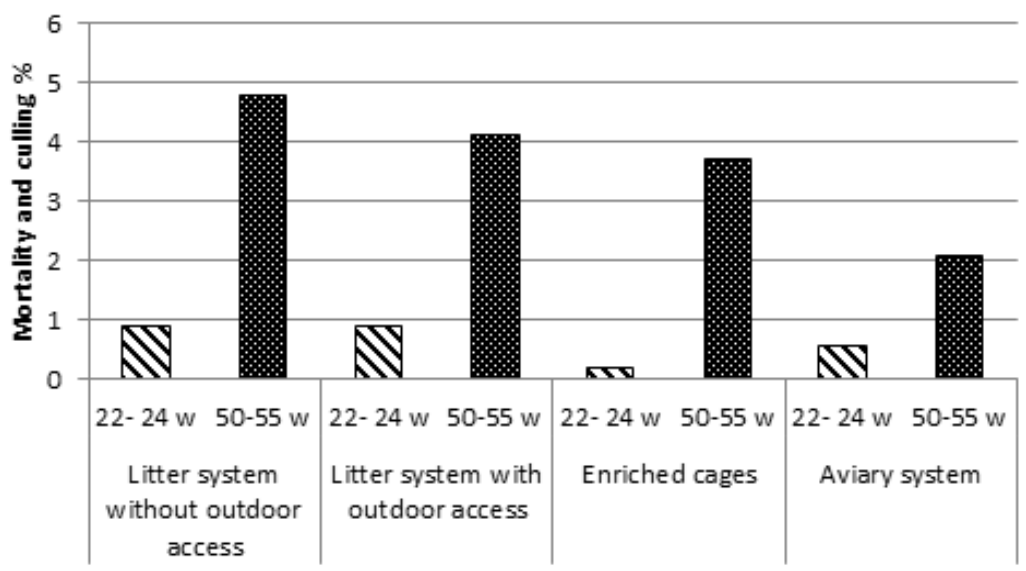

Figure 1: Cumulative mortality and culling per age and housing system

Table 2: Average values of selected climate parameters at both visits (V1, V2)

\begin{tabular}{lccccccccc}
\hline \multirow{2}{*}{ Parameter } & \multicolumn{2}{c}{$\begin{array}{c}\text { Litter system, no } \\
\text { outdoor access }\end{array}$} & \multicolumn{2}{c}{$\begin{array}{c}\text { Litter system, } \\
\text { outdoor access }\end{array}$} & \multicolumn{2}{c}{$\begin{array}{c}\text { Enriched } \\
\text { cages }\end{array}$} & \multicolumn{2}{c}{$\begin{array}{c}\text { Aviary } \\
\text { system }\end{array}$} \\
\cline { 2 - 11 } & $\mathrm{V} 1$ & $\mathrm{~V} 2$ & $\mathrm{~V} 1$ & $\mathrm{~V} 2$ & $\mathrm{~V} 1$ & $\mathrm{~V} 2$ & $\mathrm{~V} 1$ & V2 \\
\hline Age (weeks) & $22-24$ & $50-55$ & $22-24$ & $50-55$ & $22-24$ & $50-55$ & $22-24$ & $50-55$ \\
\hline Inside temp. $\left({ }^{\circ} \mathrm{C}\right)$ & 13.6 & 20.1 & 13.6 & 19.3 & 20.3 & 13.5 & 20.5 & 18.9 \\
\hline $\mathrm{NH}_{3}(\mathrm{ppm})$ & 24 & 4.3 & 24 & 4.3 & nd & nd & 4 & 3 \\
\hline Rel. humidity $(\%)$ & 66.8 & 74.2 & 66.8 & 74.2 & 69.9 & 68.1 & 58.4 & 55.3 \\
\hline Airflow $(\mathrm{m} / \mathrm{s})$ & 0.23 & 0.126 & 0.23 & 0.126 & 0.21 & 0.43 & 0.19 & 0.22 \\
\hline
\end{tabular}

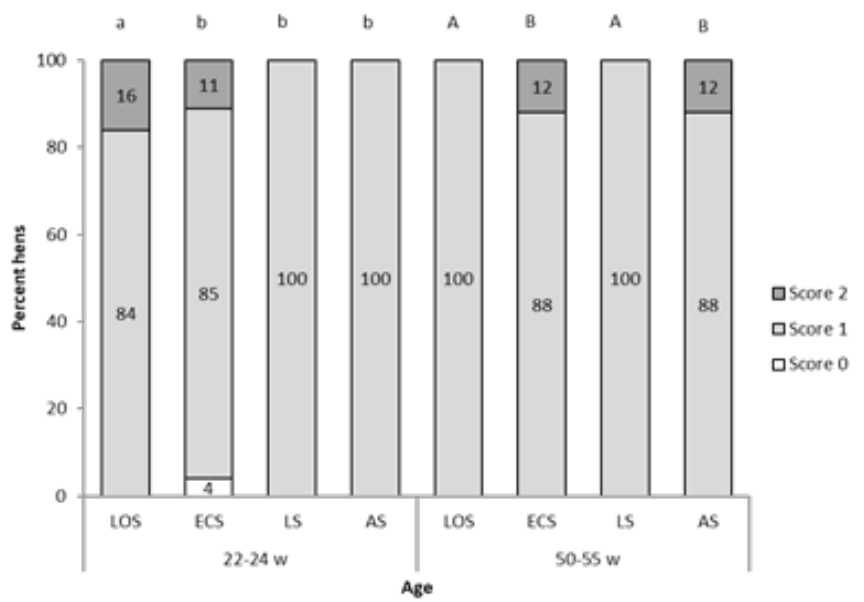

Figure 2: Percentage of hens with beak abnormalities at 22 to 24 and 50 to 55 weeks of age housed in a litter system with outdoor access (LOS), enriched cages (ECS), a litter system (LS), and an aviary system (AS). Beaks were scored 0 when no abnormalities were observed, 1 if abnormalities were mild, and 2 if severe. Bars with different letters (lower-case letters for the first assessment, upper-case letters for the second assessment) indicate significant differences $(p<0.05)$ between housing systems

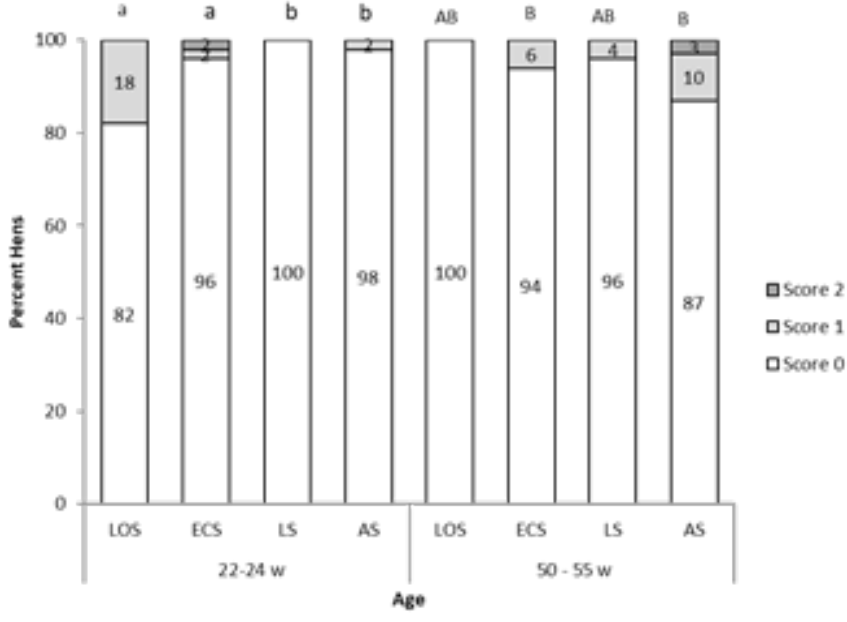

Figure 3: Percentage of hens with comb wounds at 22 to 24 and 50 to 55 weeks of age housed in a litter system with outdoor access (LOS), enriched cages (ECS), a litter system (LS), and an aviary system (AS). Combs were scored 0 when no wounds were observed, 1 if fewer than three fresh wounds were present, and 2 if three or more fresh wounds were present. Bars with different letters (lower-case letters = first assessment, uppercase letters $=$ second assessment) indicate significant differences $(p<0.05)$ between housing systems 


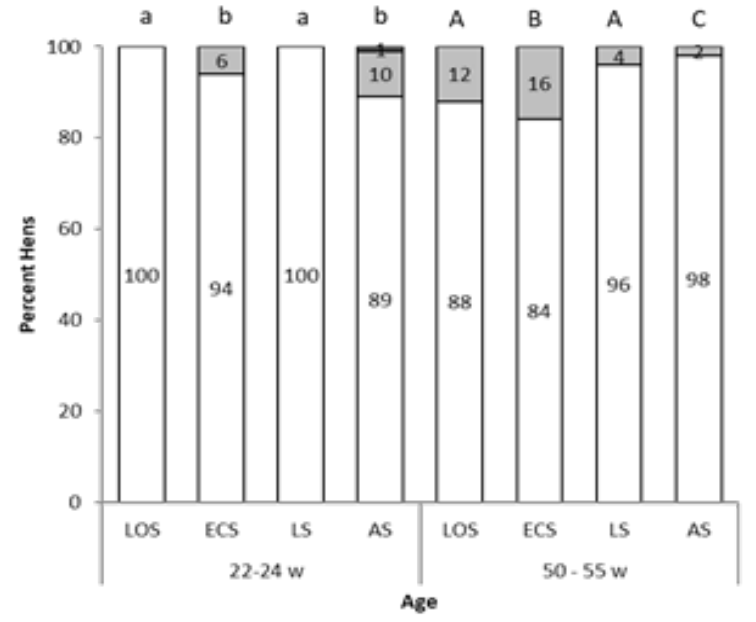

Figure 4: Percentage of hens with foot abnormalities at 22 to 24 and 50 to 55 weeks of age housed in a litter system with outdoor access (LOS), enriched cages (ECS), a litter system (LS), and an aviary system (AS). Foot lesions were scored 0 when no lesions were present, 1 if proliferation of epithelium was seen, and 2 if there was swelling on the dorsal surface of the foot. Bars with different letters (lower-case letters = first assessment, upper-case letters = second assessment) indicate significant differences $(p<0.05)$ between housing systems

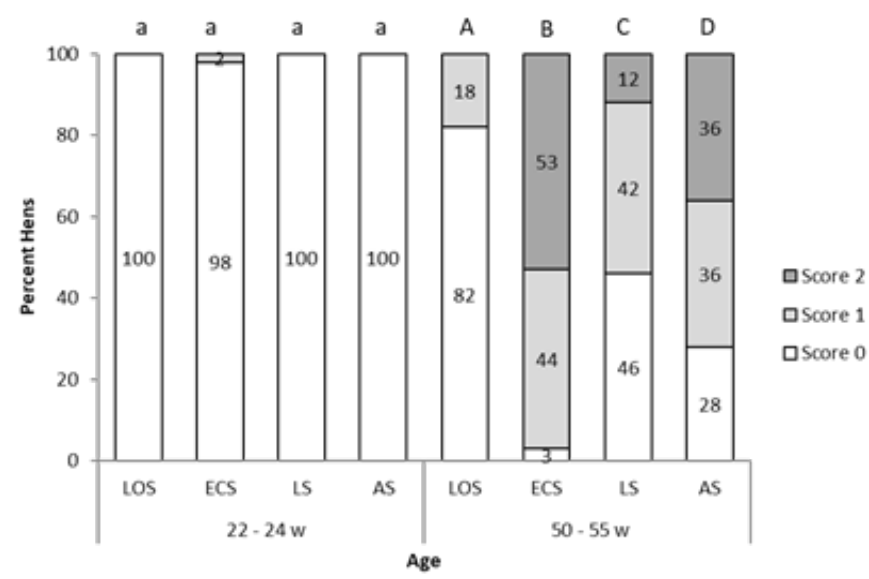

Figure 6: Percentage of hens with feather damage at 22 to 24 and 50 to 55 weeks of age housed in a litter system with outdoor access (LOS), enriched cages (ECS), a litter system (LS), and an aviary system (AS). Feather condition was scored 0 when a hen was completely or almost completely feathered, 1 if damaged feathers or one or more featherless areas $<5 \mathrm{~cm}$ in diameter were present, and 2 if there was at least one featherless area $\geq 5 \mathrm{~cm}$ in diameter present. Bars with different letters (lower-case letters = first assessment, upper-case letters $=$ second assessment) indicate significant differences $(p<0.05)$ between housing systems.

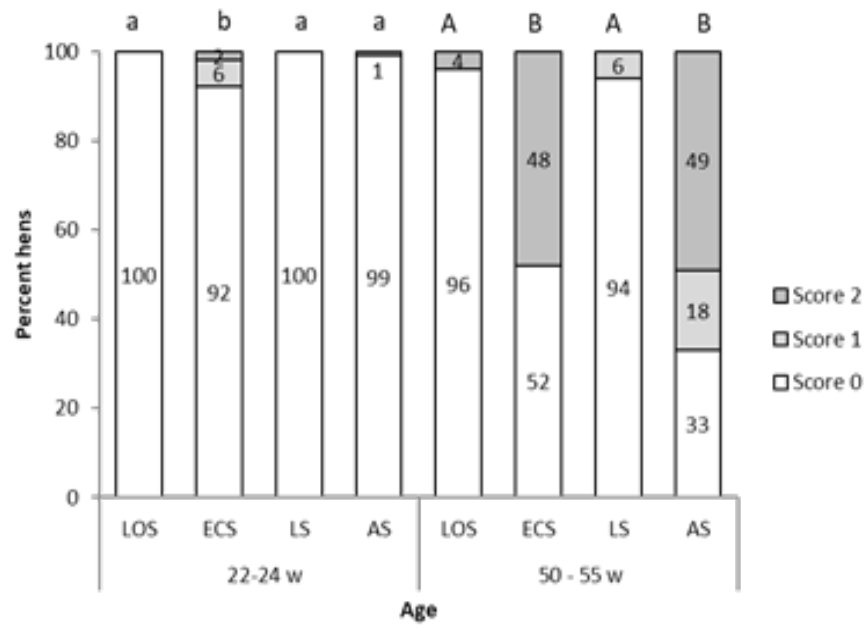

Figure 5: Percentage of hens with keel bone damage at 22 to 24 and 50 to 55 weeks of age housed in a litter system with outdoor access (LOS), enriched cages (ECS), a litter system (LS), and an aviary (AS). Keel bone damage was scored 0 when there was no deformation, 1 if minor S-shaped deviation was observed, and 2 if there were severe keel deformities. Bars with different letters (lower-case letters $=$ first assessment, upper-case letters $=$ second assessment) indicate significant differences $(p<$ 0.05) between housing systems.

\section{Keel bone deformities}

Keel bone damage was observed in $8 \%$ of the ECS hens at the first visit. Although one severe deformity was scored in the AS, there was no significant difference between the AS and both litter systems at this age $(p>0.05)$. At the second visit, the highest score of keel bone deviations was confirmed in the AS, followed by the ECS, but the difference was not significant $(p>0.05)$. In the litter system with or without outdoor access, significantly $(p<0.05)$ fewer hens with keel bone damage were identified (Figure 5).

\section{Feather condition}

A difference in feather condition between hens in different systems was found during the second visit $(p<0.05)$ but not the first $(p>0.05)$. The hens in the ECS had the highest score, followed by the AS and LS. The lowest score was recorded in the LOS, where $18 \%$ of hens scored 1 (Figure 6).

The similarity of proportions between housingsystem and animal-based welfare indicators is presented in Table 3. The results show that except for comb wounds all other indicators differentiate between housing systems.

The relationship between animal-based welfare indicators and hens' age was tested using Fisher's exact test (Table 4). 
Table 3: Occurrence of clinical welfare indicators in hens from different housing systems

\begin{tabular}{|c|c|c|c|c|c|c|}
\hline \multirow[b]{2}{*}{ Parameter } & \multirow[b]{2}{*}{ Score } & \multicolumn{4}{|c|}{ Housing system } & \multirow{2}{*}{$\begin{array}{c}\text { Fisher's exact } \\
\text { test } \\
p \text {-value }\end{array}$} \\
\hline & & $\begin{array}{c}\text { LOS } \\
(n=100)\end{array}$ & $\begin{array}{c}\text { ECS } \\
(n=200)\end{array}$ & $\begin{array}{c}\mathrm{LS} \\
(n=100)\end{array}$ & $\begin{array}{c}\text { AS } \\
(n=200)\end{array}$ & \\
\hline \multirow[t]{3}{*}{ Feather condition } & 0 & 91 & 102 & 73 & 128 & $<1 \mathrm{e}-07^{*}$ \\
\hline & 1 & 9 & 46 & 21 & 36 & \\
\hline & 2 & 0 & 53 & 6 & 36 & \\
\hline \multirow[t]{3}{*}{ Keel bone damage } & 0 & 98 & 144 & 97 & 132 & $<1 \mathrm{e}-07^{*}$ \\
\hline & 1 & 0 & 6 & 3 & 18 & \\
\hline & 2 & 2 & 50 & 0 & 50 & \\
\hline \multirow[t]{3}{*}{ Comb wounds } & 0 & 91 & 190 & 98 & 185 & 0.2115 \\
\hline & 1 & 9 & 8 & 2 & 12 & \\
\hline & 2 & 0 & 2 & 0 & 3 & \\
\hline \multirow[t]{3}{*}{ Skin lesions } & 0 & 98 & 197 & 100 & 194 & $0.0008^{*}$ \\
\hline & 1 & 2 & 3 & 0 & 6 & \\
\hline & 2 & 0 & 0 & 0 & 0 & \\
\hline \multirow[t]{3}{*}{ Foot pad lesions } & 0 & 94 & 178 & 98 & 187 & $0.03492^{*}$ \\
\hline & 1 & 0 & 22 & 2 & 12 & \\
\hline & 2 & 0 & 0 & 0 & 1 & \\
\hline \multirow[t]{3}{*}{ Beak deformities } & 0 & 0 & 4 & 0 & 0 & $0.00019^{*}$ \\
\hline & 1 & 92 & 173 & 100 & 188 & \\
\hline & 2 & 8 & 23 & 0 & 12 & \\
\hline
\end{tabular}

*An asterisk indicates significant differences in the occurrence of clinical welfare indicators at different ages at the 0.05 level using Fisher's exact test

Table 4: Occurrence and scores of clinical welfare indicators at two ages

\begin{tabular}{|c|c|c|c|c|}
\hline \multirow[t]{2}{*}{ Parameter } & \multirow[t]{2}{*}{ Score } & \multicolumn{2}{|c|}{ Observation period } & \multirow{2}{*}{$\begin{array}{l}\text { Fisher's exact test } \\
p \text {-value }\end{array}$} \\
\hline & & $22-24 \mathrm{w}(n=300)$ & $50-55 \mathrm{w}(n=300)$ & \\
\hline \multirow[t]{3}{*}{ Feather condition } & 0 & 298 & 95 & $<2.2 \mathrm{e}-16^{*}$ \\
\hline & 1 & 2 & 110 & \\
\hline & 2 & 0 & 95 & \\
\hline \multirow[t]{3}{*}{ Keel bone damage } & 0 & 291 & 180 & $<2.2 \mathrm{e}-16^{*}$ \\
\hline & 1 & 6 & 21 & \\
\hline & 2 & 3 & 99 & \\
\hline \multirow[t]{3}{*}{ Foot pad lesions } & 0 & 283 & 274 & 0.149 \\
\hline & 1 & 16 & 26 & \\
\hline & 2 & 1 & 0 & \\
\hline \multirow[t]{3}{*}{ Skin wounds } & 0 & 283 & 296 & 0.566 \\
\hline & 1 & 7 & 4 & \\
\hline & 2 & 0 & 0 & \\
\hline \multirow[t]{3}{*}{ Comb wounds } & 0 & 285 & 279 & 0.601 \\
\hline & 1 & 13 & 13 & \\
\hline & 2 & 2 & 3 & \\
\hline \multirow[t]{3}{*}{ Beak deformities } & 0 & 4 & 0 & 0.1147 \\
\hline & 1 & 277 & 276 & \\
\hline & 2 & 19 & 24 & \\
\hline
\end{tabular}

*An asterisk indicates significant differences in the occurrence of clinical welfare indicators among housing systems at the 0.05 level using Fisher's exact test 
Table 5: Average results of the NOT and ADT obtained at different observation periods in four different housing systems

\begin{tabular}{lccccc}
\hline & \multicolumn{2}{c}{$\begin{array}{c}\text { Novel object test }{ }^{1} \\
\text { (average hens close to the NO) }\end{array}$} & & \multicolumn{2}{c}{$\begin{array}{c}\text { Avoidance distance test }{ }^{2} \text { (mean avoidance } \\
\text { distance in cm and range) }\end{array}$} \\
\cline { 2 - 3 } \cline { 5 - 6 } System & $22-24$ weeks & $50-55$ weeks & & $22-24$ weeks & $50-55$ weeks \\
\hline LS & 0.68 & 0.75 & & $33.10(10-100)$ & $30.70(10-120)$ \\
LOS & 0.68 & 0.74 & & $32.99(10-100)$ & $28.09(10-100)$ \\
ECS & 0.21 & 0.39 & & $19.20(10-30)$ & $20.90(15-50)$ \\
AV & 2.28 & 3.56 & & $16.70(10-50)$ & $17.15(10-60)$ \\
\hline
\end{tabular}

${ }^{1}$ Average of observations performed at four locations

${ }^{2}$ Average of 21 hens scored at three locations

The results showed that feather condition and keel bone damage were associated with hens' age.

\section{Hens' behavior}

Hens' behavior was scored on the NOT and the ADT, and the results are presented in Table 5. At both visits the highest average count of birds close to the NO was in the AS. In the ADT, a larger average distance indicative of increased fearfulness of humans was recorded in the LS hens, followed by the LOS and ECS hens. The overall results show that the AS hens expressed less general fearfulness as well as a better humananimal relationship compared to hens kept in the other three systems.

\section{Discussion}

This study evaluated some aspects of welfare in the four most common rearing systems for layers used in Slovenia; enrichment battery cages, aviaries, and litter systems with or without outdoor access. To investigate the possible development of selected welfare indicators with age, assessments were performed at two time points; at the beginning of the laying period at 2224 weeks and at 50-55 weeks of age. The results suggest that the intensive housing conditions for laying hens in Slovenia are satisfactory from the health and welfare point of view. Finding a better psychological profile for birds in the aviary system on a small family farm may emphasize the importance of human contact for birds' welfare.

Records of the clinical condition of farm animals such as mortality or diseases are among the earliest welfare indicators used (7). The four flocks included in our study were in good health, and no obvious clinical signs related to infection diseases were seen. In the ECS hens, infestation with Dermanyssus gallinae was confirmed at the second assessment. The flock was treated with Byemite $^{\circledR}$ and no obvious effect on mortality was noted. The mortality from placement to 50 to 55 weeks of age did not exceed the expected rate for each farm. The lowest cumulative mortality was recorded in the AS hens (2.1\%), followed by the ECS (3.7\%) and both litter systems (4.2 and 4.8\%). Mortality rates in layer flocks have previously been reported between 2.9 to $15.5 \%$ in enriched cages (8), and 5 to $20 \%$ for non-cage systems (6). Weeks (9) conducted a quantitative analysis on the mortality of 3,851 commercial flocks recorded across Europe. The results showed that mortality rates in layer flocks tend to be higher in non-cage systems compared to enriched cage systems. In addition, a review by Nicol (10) noted that mortality in free-range and aviary systems is highly variable.

Air quality in the housing systems could have an important effect on health. High concentrations of ammonia can have adverse health effects and, when very high, can even influence production performance. The most profound effects seen are lesions in the respiratory tract and keratoconjunctivitis (11). According to European regulations $(12,13)$, occupational exposure limit values are set at $20 \mathrm{ppm}$. Slightly exceeded levels of ammonia were recorded at the first assessment in the facilities with litter systems. It is known that concentrations of ammonia could be high in floor housing systems in which manure is not regularly removed. Both observations were made in the winter, and the levels of ammonia might be due to reduction of ventilation to maintain a suitable indoor temperature. Overall, it can be concluded that the indoor climate was satisfactory in all systems. 
This study showed that the condition of the keel bone and feathers in layers housed in various housing systems in Slovenian commercial farms were affected by hens' age, and that the ECS and AS were associated with significantly more keel deformities and poorer feather condition compared to the litter systems.

The keel bone is known to be a site of frequent fractures during the production life of laying hens, with incidence rates ranging from 5\% to over $85 \%$, and it is known that hens in all types of housing systems are susceptible to keel fractures (14). Several studies have also shown that the prevalence of keel bone fractures increases throughout the laying period (15-18). In our study, keel bone deformities were already detected at the beginning of the laying period in the ECS and AS hens. These early deformities could be caused by the keels being damaged during handling or transport from rearing to the production facility. Although keel bone damage was observed at the second assessment in all systems compared, the differences between systems were significant. Moderate to severe deformities were found in $67 \%$ of the AS hens and $48 \%$ of the ECS hens, whereas in the LOS and LS hens only 4 to $6 \%$ had keel bone deformities. Bone fragility in laying hens is related to high egg production, musculoskeletal health, and restricted movements (19). However, bone fractures are a risk when hens fall during flight on objects such as perches, feeders, and drinkers within the facility, which might be the main reason for the high occurrence of keel bone damage found in the AS. On the other hand, hens housed in the ECS are less active than in noncage systems, which increases the susceptibility to weak bones and osteoporosis (17).

Previous studies comparing feather damage in different housing systems have reported diverging results; some studies showed a lower prevalence in cage system compared to non-cage system $(20,21)$. On the contrary, other studies showed a higher prevalence in hens housed in enrichment cages compared to hens housed in litter systems (22). The poor feather condition found in almost all the ECS hens in our study might also be linked to the red mite infestation that was present in the facility. The presence of mites in a production house induces a high level of stress from pain and skin irritation associated with repeated mite bites. In addition, mite infestations induce increased self-grooming and aggressive feather-pecking behavior (23).
Foot lesions are present in laying hens housed in all systems, although some studies have indicated that layers in enriched cages have better foot health than those in other production systems (19). Wet litter, a high level of ammonia, and poorly designed and maintained perches have been associated with foot injuries in litter systems $(19,24,25)$. In cage systems, hens are kept on wire mesh, which may cause superficial epithelial lesions and hyperkeratosis $(26,27)$. In this study the occurrence of foot injuries was low and almost no severe inflammation (i.e., bumblefoot) was seen in any system. At both observations, hens kept in systems using wire mesh as flooring material (the AS and ECS at the first assessment and the ES at the second assessment) had more foot pad dermatitis compared to both litter systems. The prevalence of foot pad lesions has previously been found to be higher in younger hens compared to older ones (17). In our study no association between hens' age and foot lesions was confirmed.

The assessment of mental wellbeing of hens was performed by using two tests included in the Welfare Quality ${ }^{\circledR}$ protocol. The NOT measures the conflicting motivation to approach and avoid a novel object (28). The time spent near a novel object can therefore be used to quantify an animal's fearfulness. The results of our study showed that the AS hens were the most motivated to approach a NO at both observation periods. The lowest numbers were obtained in the ECS hens, possibly because of the lack of free space and because the object was not visible for all hens. In the ADT, which reflects animals' fear of humans (29), hens in both litter systems showed more fear compared to the AS hens. However, it should be mentioned that the results of both tests in the ECS might be difficult to compare with non-cage systems because there is a wire door between the observer and hens. It was shown that hens in large commercial facilities tend to be fearful of human contact (30) and that fearfulness can be reduced through appropriate familiarization (31). Three flocks (ECS, LOS, and LS) in our study were housed on large commercial farms, whereas the hens from the AS were kept on a small family farm. At both assessments these hens expressed less general fearfulness and a better humananimal relationship compared to hens from other systems. A review by Nicol noted that fearfulness might be better correlated with the quality of human contact that hens are exposed to more 
than with rearing systems (10), which may also be the case in our study.

This study is the first to provide results of welfare indicators of commercial layers in Slovenia. We cannot assume that our restricted sample of flocks is representative for the commercial hen industry in Slovenia, but it offers some estimation of the problems that may exist, such as keel bone damage.

\section{Acknowledgements}

This work was financially supported by the Slovenian Ministry of Agriculture, Forestry, and Food and the Slovenian Research Agency, project number V-4 1604.

\section{References}

1. Council Directive 1999/74/EC of 19 July 1999. Laying down minimum standards for the protection of laying hens. Off $\mathrm{J}$ Eur Commun 1999; L203: 53-7.

2. European Commission. EU market situation for eggs. Committee for the common organisation of the agricultural markets: 18 June 2020: video meeting [online]. https://ec.europa.eu/agriculture/eggs/presentations_en

3. Končni podatki o številu živine v letu 2018 [online]. Ljubljana : Statistični urad RS. https:// www.stat.si/StatWeb/News/Index/8019

4. Zaščita rejnih živali [online]. Ljubljana : Urad za varno hrano veterinarstvo in varstvo rastlin RS. https://www.gov.si/teme/dosezki-in-iniciative-na-podrocju-dobrobiti-rejnih-zivali/

5. Welfare Quality. The Welfare Quality ${ }^{\circledR}$ assessment protocol for poultry (broilers, laying hens). Lelystad: The Welfare Quality ${ }^{\circledR}$ Consortium, 2009: $112 \mathrm{p}$.

6. Blokhuis HJ, Veissier I, Miele M, Jones B. The Welfare Quality ${ }^{\circledR}$ project and beyond: safeguarding farm animal well-being. Acta Agric Scand A 2010; 60(3): 129-40.

7. Rodenburg TB, Tuyttens FAM, de Reu K, Herman L, Zoons J, Sonck B. Welfare assessment of laying hens in furnished cages and noncage systems: an on-farm comparison. Anim Welf 2008; 17(4): 363-73.

8. Sherwin CM, Richards GJ, Nicol CJ. Comparison of the welfare of layer hens in 4 housing systems in the UK. Br Poult Sci 2010; 51(4): 488-99.
9. Weeks CA, Lambton SL, Williams AG. Implications for welfare, productivity and sustainability of the variation in reported levels of mortality for laying hen flocks kept in different housing systems: a meta-analysis of ten studies. PLoS One 2016; 11(1): e0146394. doi: 10.1371/journal. pone. 0146394

10. Nicol CJ, Bouwsema J, Caplen G, et al. Farmed bird welfare science review. Melbourne: Department of Economic Development, Jobs, Transport and Resources, 2017: 321.

11. David B, Mejdell C, Michel V, Lund V, Moe RO. Air quality in alternative housing systems may have an impact on laying hen welfare. Part II-ammonia. Animals 2015; 5(3): 886-96. doi: 10.3390/ani5030389

12. EC. Commission Directive 2000/39/EC of 8 June 2000 establishing a first list of indicative occupational exposure limit values in implementation of Council Directive 98/24/EC on the protection of the health and safety of workers from the risks related to chemical agents at work. Off J Eur Commun 2000; L142: 47-50. https://eurlex.europa.eu/legal-content/en/ALL/?uri=CELEX\%3A32000L0039

13. EC. Council Directive 98/24/EC of 7 April 1998 on the protection of the health and safety of workers from the risks related to chemical agents at work (fourteenth individual Directive within the meaning of Article 16(1) of Directive 89/391/ EEC) Off $\mathrm{J}$ Eur Commun 1998; L131: 11-23. https://eur-lex.europa.eu/legal-content/EN/TX$\mathrm{T} /$ ?uri $=$ celex\%3A31998L0024

14. Riber AB, Casey-Trott TM, Herskin MS. The influence of keel bone damage on welfare of laying hens. Front Vet Sci 2018; 5: e6. doi: 10.3389/ fvets.2018.00006

15. Fleming RH, McCormack HA, McTeir L, Whitehead CC. Incidence, pathology and prevention of keel bone deformities in the laying hen. $\mathrm{Br}$ Poult Sci 2004; 45(3): 320-30.

16. Petrik MT, Guerin MT, Widowski TM. Onfarm comparison of keel fracture prevalence and other welfare indicators in conventional cage and floor-housed laying hens in Ontario, Canada. Poult Sci 2015; 94(4): 579-85.

17. Riber AB, Hinrichsen LK. Keel-bone damage and foot injuries in commercial laying hens in Denmark. Anim Welf 2016; 25(2): 179-84.

18. Sandilands V, Moinard C, Sparks NHC. Providing laying hens with perches: fulfilling behavioural needs but causing injury? Br Poult Sci 
2009; 50(4): 395-406.

19. Lay DC, Fulton RM, Hester PY, et al. Hen welfare in different housing systems. Poult Sci 2011; 90(1): 278-94.

20. Blokhuis HJ, Van Niekerk TF, Bessei W, et al. The LayWel project: welfare implications of changes in production systems for laying hens. World Poult Sci J 2007; 63(1): 101-14.

21. Rorvang MV, Hinrichsen LK, Riber AB. Welfare of layers housed in small furnished cages on Danish commercial farms: the condition of keel bone, feet, plumage and skin. Br Poult Sci 2019; 60(1): 1-7.

22. Pichova K, Bilcik B, Kost'al L. Assessment of the effect of housing on feather damage in laying hens using IR thermography. Animal 2017; 11(4): 661-9. doi: $10.1017 /$ S1751731116001981

23. Flochlay AS, Thomas E, Sparagano O. Poultry red mite (Dermanyssus gallinae) infestation: a broad impact parasitological disease that still remains a significant challenge for the egg-laying industry in Europe. Parasit Vectors 2017; 10(1): e357. doi: 10.1186/s13071-017-2292-4.

24. Tauson R, Abrahamsson P. Foot and skeletal disorders in laying hens: effects of perch design, hybrid, housing system and stocking density. Acta Agric Scand A 1994; 4(2): 110-9.

25. Wang G, Ekstrand C, Svedberg J. Wet litter and perches as risk factors for the development of foot pad dermatitis in floor-housed hens. Br Poult
Sci 1998; 39(2): 191-7.

26. Weitzenburger D, Vits A, Hamann $H$, Hewicker-Trautwein M, Distl O. Evaluation of foot pad health of laying hens in small group housing systems and furnished cages. Berl Munch Tierarztl Wochenschr 2005; 118(7/8): 270-9.

27. Roenchen S, Scholz B, Hamann H, Distl O. Foot pad health, plumage condition, integument and claw length of Lohmann Silver laying hens kept in small aviary housing systems, furnished cages and an aviary housing system. Arch Tierzucht 2007; 50(4): 388-402.

28. Stankowich T, Blumstein DT. Fear in animals: a meta-analysis and review of risk assessment. Proc Biol Sci 2005; 272(1581): 2627-34.

29. Niekerk T, Gunnink H, Reenen K. Welfare Quality ${ }^{\circledR}$ assessment protocol for laying hens. Report No. 589. Lelystad : Wageningen UR Livestock Research, 2012.

30. Graml C, Niebuhr K, Waiblinger S. Reaction of laying hens to humans in the home or a novel environment. Appl Anim Behav Sci 2008; 113(1/3): 98-109.

31. Edwards LE, Coleman GJ, Hemsworth PH. Close human presence reduces avoidance behaviour in commercial caged laying hens to an approaching human. Anim Prod Sci 2013; 53(12): $127-82$.

\title{
OCENA DOBROBITI V INTENZIVNIH REJAH KOKOŠI NESNIC V SLOVENIJI
}

\author{
O. Zorman Rojs, A. Dovč, H. Hristov, M. Červek, B. Slavec, U. Krapež, Z. Žlabravec, J. Račnik, M. Zupan
}

Povzetek: Opravili smo prvo celovito oceno dobrobiti kokoši nesnic v Sloveniji. V raziskavo smo vključili nesnice izštirih različnih sistemov reje in raven dobrobiti ocenili v dveh starostnih obdobjih; na začetku nesnosti, v starosti od 22 do 24 tednov in pri 50 do 55 tednih. Nesnice so bile rejene v obogatenih kletkah, v voljerah, v talni reji brez možnosti izpusta in v talni reji z možnostjo izpusta. Ob vsakem ocenjevanju smo jate klinično pregledali in s pregledom posameznih živali ocenili specifične indikatorje dobrega počutja (poškodbe prsnice, operjenost, poškodbe podplatnih blazinic, deformacije kljuna in poškodbe grebena ter kože). Plašnost kot indikator socialnega obnašanja smo ocenili s testom novega predmeta in s testom odmika od človeka. Spremljali smo tudi mikro-klimatske pogoje reje.

Ves čas spremljanja nismo ugotovili vidnih kliničnih znakov kužnih obolenj. Rezultati meritev mikro-klimatskih parametrov nakazujejo, da so bili pogojiv rejah dobri. Poškodba prsnice se je izmed specifičnih kazalnikovizkazala za najresnejši problem, nakaterega vplivata tako starost kot sistem reje $(p<0,05)$. Poškodbe prsnice so bile značilno bolj izražene pri kokoših iz obogatenih kletk in voljer $(p<0,05)$ v primerjavi z nesnicami iz talnih rej. Kokoši iz talnih sistemov so bile tudi boljše operjene in so imele nižjo prevalenco poškodb na podplatnih blazinicah. Nesnice, ki so bile rejene v voljerah na družinski kmetiji, so kazale največ zanimanja za nove predmete in človeka. Te kokoši so bile ocenjene kot najmanj plašne in so izražale boljšo interakcijo človek-žival kot kokoši iz drugih primerjanih sistemov.

Ključne besede: kokošinesnice; dobrobit; zdravje; sistem reje 